\title{
Neoadjuvant Treatment with Taxanes in Breast Cancer
}

\author{
Gunter von Minckwitz \\ German Breast Group, Universitäts-Frauenklinik Frankfurt/M., Germany
}

\section{Key Words}

Docetaxel - Paclitaxel - Neoadjuvant - Preoperative . Chemotherapy · Breast cancer

\section{Summary}

Today, primary breast cancer is considered a systemic disease with a locoregional component. Systemic treatment, therefore, represents a fundamental aspect of the medical management of patients suffering from this pandemic malignancy. As at least equal efficacy has been shown for pre- and postoperative administration of a variety of cytotoxic treatments, preoperative chemotherapy is widely accepted today as an option to reduce the extent of surgery, to obtain freedom from locoregional and distant disease, and to obtain early information on tumor responsiveness. Several phase III studies have shown a higher chance of reaching these goals if treatment includes docetaxel or paclitaxel. Both taxanes are now recommended for standard preoperative systemic treatment in many countries. They have been used as monotherapy, in combination, or in sequence with anthracyclines. However, the question of whether the sequential or the simultaneous administration of anthracyclines and taxanes is superior, remains unsolved. Moreover, the impact of treatment duration on efficacy, which is usually longer for sequential regimens, is unknown in the neoadjuvant setting. Improved prediction of response by early sonographic response evaluation, or even better by tissue markers determined on diagnostic core biopsy will help to improve the selection of optimal candidates for specific cytotoxic treatment, as well as to avoid ineffective treatment in patients with resistant tumors.

\author{
Schlüsselwörter \\ Docetaxel · Paclitaxel · Neoadjuvant · Präoperativ · \\ Chemotherapie $\cdot$ Mammakarzinom
}

\section{Zusammenfassung}

Das primäre Mammakarzinom ist heute als eine systemische Erkrankung mit lokoregionaler Komponente definiert. Die Systemtherapie stellt somit einen wesentlichen Bestandteil des medizinischen Managements von Patientinnen dar, die an dieser pandemischen Erkrankung leiden. Da zumindest eine gleich hohe Effektivität für die Applikation vor und nach der Operation für eine Vielzahl von Zytostatikaregimen gezeigt werden konnte, ist die präoperative Chemotherapie heute als eine valide Option zur Verringerung des Ausmaßes der Operation, zur vollständigen Elimination lokoregionaler und distanter Tumoranteile und zum frühen Erhalt von Informationen zum Tumoransprechen etabliert. In mehreren Phase-IIIStudien konnte eine höhere Chance für das Erreichen dieser oben genannten Ziele mit docetaxel- oder paclitaxelhaltigen Therapien gezeigt werden. Beide Taxane werden mittlerweile in vielen Ländern im Rahmen neoadjuvanter Standardtherapien empfohlen. Wesentliche offene Fragen zu diesem Therapieansatz sind: ist die simultane oder die sequentielle Applikation von Taxanen und Anthrazyklinen vorteilhafter; sind Behandlungen mit längerer Zeitdauer effektiver; und wie kann durch eine Vorhersage des Ansprechens, z.B. durch eine frühe Bestimmung des Ansprechens mittels Ultraschall oder besser durch die Bestimmung von Gewebefaktoren an der prätherapeutischen Stanzbiopsie, die Auswahl optimaler Kandidaten für eine spezifische Chemotherapie verbessert bzw. eine ineffektive Behandlung von Patientinnen mit resistenten Tumoren vermieden werden.

\begin{tabular}{ll}
\hline KARGER & ๑ 2006 S. Karger GmbH, Freiburg \\
Fax +49761 4520714 & Accessible online at: \\
$\begin{array}{l}\text { E-mail Information@Karger.de } \\
\text { www.karger.com }\end{array}$ & www.karger.com/brc
\end{tabular}

Prof. Dr. Gunter von Minckwitz

German Breast Group / Universitäts-Frauenklinik Frankfurt Schleussner-Straße 42

63263 Neu-Isenburg, Germany

Tel. +49 6102 79874-10, Fax -40

E-mail minckwitz@germanbreastgroup.de 


\section{Current Status of Neoadjuvant Chemotherapy in Patients with Primary Breast Cancer}

Primary systemic therapy has been considered for a long time as the standard treatment for patients with inoperable primary breast cancer. This includes patients with locally advanced tumors in whom surgery will most likely achieve insufficient local control. This is usually the case in the tumor stages IIIA/IIIB or T3/T4, classic inflammatory breast cancer, or involvement of ipsilateral supra- or infraclavicular lymphnodes (N3). Although this approach has never been tested against a primary surgical approach in large randomized clinical trials, there is general agreement about this strategy [1].

Nowadays, with operable breast cancer, preoperative chemotherapy is considered as an equally effective alternative to adjuvant postoperative systemic treatment. If the indication for cytotoxic treatment is already justified based on available pretreatment factors, doctors are advised to inform their patients about the various possibilities regarding the timing of treatment. All large scale randomized trials comparing primary systemic therapy to adjuvant systemic therapy have shown that these approaches offer equivalent disease-free survival and overall survival benefit. The neoadjuvant approach is increasingly considered as a reasonable alternative for patients with operable breast cancer who i) are deemed to be appropriate candidates for mastectomy but who desire less extensive surgery (e.g. breast-conserving surgery); ii) can technically have a lumpectomy up-front but whose physical appearance will be less damaged if primary systemic therapy is given first; iii) want to take advantage of the response assessment of the primary tumor before it is removed, as a demonstrable response to primary systemic therapy may have a positive effect on the patient's compliance with further treatment and on the patient's willingness to accept certain adverse events; iv) may have medical contraindications to surgery or may simply wish to delay surgery (for example, primary systemic therapy can be used in the second or third trimester in pregnant patients diagnosed with breast cancer, followed by surgery and radiotherapy after delivery).

\section{Efficacy Data on the Neoadjuvant Use of Docetaxel or Paclitaxel}

Women were in general eligible for these trials if they had a unilateral histologically or, in older trials, only cytologically proven breast tumor with no evidence of metastases and were otherwise healthy, with no history of malignancy, no previous cytotoxic or endocrine therapy, and no evidence of abnormal cardiac function. In the majority of these trials, patients with both operable and locally advanced tumors were eligible. As tumor size could not be identified as a reliable predictor of treatment efficacy, this heterogeneity appears to not influence response rates negatively. More importantly, small trial sample
Table 1. Improvement in pCR rates by addition of taxanes to neoadjuvant chemotherapy protocols

\begin{tabular}{lllc}
\hline Year & Regimen & Reference & pCR, \% ${ }^{\mathrm{a}}$ \\
\hline 1980 & CMF & & 3 \\
1990 & EC & & 6 \\
1999 & AD & {$[23]$} & 11 \\
2002 & E-P & {$[22]$} & 18 \\
2001 & AC-D & {$[23,25]$} & 22 \\
2003 & DAC & {$[10]$} & 23 \\
2005 & EC-PH & {$[29]$} & $26^{\mathrm{b}}$ \\
\hline
\end{tabular}

aPercent of patients with operable breast cancer.

${ }^{\mathrm{b}}$ Her2-positive patients only.

pCR $=$ Pathological complete remission $; \mathrm{C}=$ cyclophosphamide

$\mathrm{M}=$ methrotrexate $\mathrm{F}=$ 5-fluorouracil; $\mathrm{E}=$ epirubicin; $\mathrm{A}=$ doxorubicin

$\mathrm{D}=$ docetaxel $\mathrm{H}=$ trastuzumab

size, small numbers of participating sites, a non-randomized trial design, and an imprecise definition of histopathologic response may lead to unusually high pathological complete response (pCR) rates which should not be directly compared with pCR rates of large scale phase III trials.

The primary endpoint in more recent trials is usually pathologic response, whereas in former trials it used to be clinical response at surgery. Today, the definition of pCR rate is recommended to be approached highly conservatively, including only those patients where no invasive or non-invasive tumor cells were found in the removed breast and lymphatic nodal tissue. Data on patients with non-invasive residuals only, focal invasive residuals, and /or positive regional nodes should be reported separately.

pCR rates have risen steadily over the last decades. Before the taxane era, they generally were below $10 \%$. With the first taxane-based treatment regimes, pCR rates increased to between 10 and $20 \%$, and only recently they are exceeding $20 \%$ (table 1 ). An overview of trials directly comparing different neoadjuvant systemic treatments is given in tables 2 and 3 with regard to $\mathrm{pCR}$ rates and breast conservation treatments. In the following, specific trials using taxanes as monotherapy, taxanes in combination, and taxanes simultaneously with anthracyclines will be discussed.

\section{Monotherapy Trials}

Preliminary results from 2 randomized, multicenter phase II trials in women with operable breast cancer showed that docetaxel monotherapy is as effective as docetaxel/epirubicin [2] or doxorubicin/cyclophosphamide [3] in the neoadjuvant setting. In the first trial $(n=60)$, similar proportions of patients receiving either 8 cycles of docetaxel $100 \mathrm{mg} / \mathrm{m}^{2}$ or 6 cycles of epirubicin $100 \mathrm{mg} / \mathrm{m}^{2}$ plus docetaxel $75 \mathrm{mg} / \mathrm{m}^{2}$ achieved pCR (Chevallier classification: 13 vs. 7\%; Sataloff classification: 17 
Table 2. Clinical trials comparing different preoperative taxane regimens as neoadjuvant chemotherapy for primary breast cancer

\begin{tabular}{|c|c|c|c|c|c|}
\hline Trial, year & Reference & Patients, $\mathrm{n}$ & Regimen 1 & Regimen 2 & $\mathrm{pCR}, \%$ \\
\hline \multicolumn{6}{|l|}{ Monotherapy trials } \\
\hline MD Anderson, 1999 & {$[4]$} & 174 & $\mathrm{FAC} \times 4$ & $\mathrm{P} \times 4$ & $\begin{array}{l}16.4 \text { vs. } 8.1^{\mathrm{a}} \\
23 \text { vs. } 14^{\mathrm{b}}\end{array}$ \\
\hline \multicolumn{6}{|l|}{ Combination trials } \\
\hline Ango-Celtic, 2005 & [31] & 363 & $\mathrm{AC} \times 6$ & $\mathrm{AD} \times 6$ & 16 vs. $12^{\mathrm{c}}$ \\
\hline French, 2004 & {$[5]$} & 200 & $\mathrm{AC} \times 4$ & $\mathrm{AP} \times 4$ & 10 vs. $16^{\mathrm{c}}$ \\
\hline Gepardo, 2001 & {$[7]$} & 248 & $\mathrm{AD}$ & $\mathrm{AD}+\mathrm{Tam}$ & 10.3 vs. $9.1^{\mathrm{d}}$ \\
\hline Milan, 2004 & {$[32]$} & 811 & $\mathrm{AP}^{*}$ & $\mathrm{EV}^{\mathrm{e}}$ & 4 vs. 8 \\
\hline ABCSG, 2004 & {$[33]$} & 292 & EDq21 $\times 3$ & $\mathrm{EDq} 21 \times 6$ & 7.7 vs. $18.6^{\mathrm{a}}$ \\
\hline Gepartrio pilot, 2004 & {$[1]$} & 286 & $\mathrm{DAC} \times 6$ & $\mathrm{DAC} \rightarrow \mathrm{NX}$ & NR: 7.3 vs. 3.1 / R: 23 \\
\hline \multicolumn{6}{|l|}{ Sequential trials } \\
\hline NSABP B-27, 2003 & {$[25]$} & 2,411 & $\mathrm{AC}$ & $\mathrm{AC} \rightarrow \mathrm{D}$ & $\begin{array}{l}9.6 \text { vs. } 18.9 \mathrm{~d} \\
13.7 \text { vs. } 26.1^{\mathrm{b}}\end{array}$ \\
\hline Geparduo, 2005 & [23] & 913 & $\mathrm{AD}$ & $\mathrm{AC} \rightarrow \mathrm{D}$ & $\begin{array}{l}7 \text { vs. } 14.3 \mathrm{c} \\
7.4 \text { vs. } 15.9 \mathrm{a} \\
11 \text { vs. } 22.3^{\mathrm{d}}\end{array}$ \\
\hline AGO, 2002 & {$[22]$} & 475 & EP & $\mathrm{E} \rightarrow \mathrm{P}$ & 10 vs. $18^{a}$ \\
\hline MD Anderson, 2005 & {$[21]$} & 258 & $\mathrm{Pq} 3 \mathrm{w} \rightarrow \mathrm{FAC}$ & $\mathrm{P} 1 \mathrm{w} \rightarrow \mathrm{FAC}$ & 13.7 vs. $28^{\mathrm{a}}$ \\
\hline Aberdeen, 2002 & {$[20]$} & 104 & CVAPr & $\mathrm{CVAPr} \rightarrow \mathrm{D}$ & 15.4 vs. $30.8^{b}$ \\
\hline
\end{tabular}

apT0/ypTis, ypN0.

${ }^{b}$ Breast only: ypT0/ypTis regardless of nodal status. cypT0, ypN0 only.

${ }^{\mathrm{d} B r e a s t}$ only: ypT0 regardless of nodal status.

ePostoperative treatment with either $\mathrm{CMF}$ or $\mathrm{T}$ in a $2 \times 2$ factorial design.

$\mathrm{A}=$ Doxorubicin; $\mathrm{E}=$ epirubicin; $\mathrm{P}=$ paclitaxel; $\mathrm{D}=$ docetaxel; $\mathrm{V}=$ vincristine; $\mathrm{H}=$ trastuzumab; $\mathrm{F}=5$-fluorouracil;

$\mathrm{C}=$ cyclophosphamide; $\mathrm{N}=$ vinorelbine; $\mathrm{X}=$ capecitabine; $\mathrm{Pr}=$ prednisolone; $\mathrm{w}=$ weekly; $\mathrm{q} 21=$ every 21 days, $\mathrm{q} 3 \mathrm{w}=$ every

3 weeks; $\mathrm{NR}=$ non-responder; $\mathrm{R}=$ responder after 2 cycles of DAC.

Table 3. Breast conservation rates after non-taxane and taxane-based neoadjuvant treatments

\begin{tabular}{|c|c|c|c|c|c|c|}
\hline \multirow[t]{2}{*}{ Study } & \multirow[t]{2}{*}{ Reference } & \multirow[t]{2}{*}{ Treatment } & \multicolumn{3}{|c|}{ BCT rate, $\%$} & \multirow[t]{2}{*}{ Trend } \\
\hline & & & AST & PST-1 & PST-2 & \\
\hline \multicolumn{7}{|l|}{ Pre vs. post } \\
\hline NSABP B-18 & {$[34]$} & $\mathrm{AC}$ & 60 & 67 & & $\uparrow$ \\
\hline ЕСТО & [8] & AP-CMF & 34 & 65 & & $\uparrow$ \\
\hline EORTC & {$[35]$} & FEC & 21 & 37 & & $\uparrow$ \\
\hline Scholl & {$[36]$} & FAC & 77 & 82 & & $\uparrow$ \\
\hline \multicolumn{7}{|l|}{ Monotherapy } \\
\hline MD Anderson & {$[28]$} & $\mathrm{FAC} / \mathrm{P}$ & & 35 & 46 & $\uparrow$ \\
\hline MD Anderson & [21] & $\mathrm{P} 3 \mathrm{w} / \mathrm{P} 1 \mathrm{w}$ & & 43 & 50 & $\uparrow$ \\
\hline \multicolumn{7}{|l|}{ Simultaneous } \\
\hline UK & {$[6]$} & $\mathrm{EC} / \mathrm{AD}$ & & 20 & 20 & $\rightarrow$ \\
\hline French & [5] & $\mathrm{AC} / \mathrm{AP}$ & & 49 & 62 & $\uparrow$ \\
\hline ABCSG & {$[33]$} & $\mathrm{ED} \times 3 / \mathrm{ED} \times 6$ & & 66 & 75 & $\uparrow$ \\
\hline Gepartrio & {$[10]$} & DAC & & & 81 & \\
\hline \multicolumn{7}{|l|}{ Sequential } \\
\hline NSABP-B27 & {$[25]$} & AC / AC-D & & 61 & 63 & $\rightarrow$ \\
\hline Geparduo & {$[23]$} & $\mathrm{AD} / \mathrm{AC}-\mathrm{D}$ & & 66 & 75 & $\uparrow$ \\
\hline AGO & {$[22]$} & EP / E-P & & 50 & 61 & $\uparrow$ \\
\hline $\begin{array}{l}\text { AST }=\text { Adjuvant } \\
\text { conservation treat } \\
\mathrm{D}=\text { docetaxel; } \mathrm{M} \\
\uparrow=\mathrm{BCT} \text { rate incr }\end{array}$ & $\begin{array}{l}\text { temic thera } \\
\text { methotrexat }-1 /-2=1 \\
\text { se } ; \rightarrow=\text { no c }\end{array}$ & $\begin{array}{l}\text { py; PST = neoadju } \\
\text { egime } 1 \text { vs. } 2 ; \mathrm{A}= \\
\text { e; } \mathrm{F}=5 \text {-fluoroura } \\
\text { hange in BCT rat }\end{array}$ & $\begin{array}{l}\text { uvant } \\
=\text { doxo } \\
\text { acil; C } \\
\text { te. }\end{array}$ & $\begin{array}{l}\text { Iry) syst } \\
\text { n; E = e } \\
\text { ophospl }\end{array}$ & $\begin{array}{l}\text { therapy } \\
\text { bicin; } \mathrm{P}= \\
\text { de; } \mathrm{w}=\end{array}$ & $\begin{array}{l}\text { breast } \\
\text { rel; }\end{array}$ \\
\hline
\end{tabular}


Table 4. Compliance (treatment discontinuation, no surgery) and treatment failure with taxane-based neoadjuvant regimens in phase III trials

\begin{tabular}{|c|c|c|c|c|c|}
\hline Study & Reference & Regimen & $\begin{array}{l}\text { Discontinuation } \\
\text { of chemotherapy, \% }\end{array}$ & No surgery, \% & $\begin{array}{l}\text { Progressive disease } \\
\text { during neoadjuvant } \\
\text { treatment, \% }\end{array}$ \\
\hline ЕСТО & {$[8]$} & $\begin{array}{l}\text { AP-CMF postop } \\
\text { AP-CMF preop }\end{array}$ & & - & - \\
\hline NSABP B-18 & {$[34]$} & $\begin{array}{l}\text { AC postop } \\
\text { AC preop }\end{array}$ & $\begin{array}{l}4.8 \\
2.3\end{array}$ & no data & - \\
\hline NSABP B-27 & {$[25]$} & $\begin{array}{l}\mathrm{AC} \\
\mathrm{AC}-\mathrm{D}\end{array}$ & $\begin{array}{l}2.2 \\
19.3\end{array}$ & $\begin{array}{l}3.0 \\
2.7\end{array}$ & $\begin{array}{l}3.0 \\
3.0\end{array}$ \\
\hline Gepardo & {$[7]$} & $\mathrm{AD}$ & 4.8 & 1.2 & 3.7 \\
\hline Geparduo & [23] & $\begin{array}{l}\mathrm{AD} \\
\mathrm{AC}-\mathrm{D}\end{array}$ & $\begin{array}{l}7.5 \\
22.6\end{array}$ & $\begin{array}{l}0.8 \\
2.0\end{array}$ & $\begin{array}{l}3.2 \\
3.7\end{array}$ \\
\hline Gepartrio & {$[10]$} & DAC / DAC-NX & 8.8 & 1.8 & 2.8 \\
\hline French & {$[5]$} & $\begin{array}{l}\mathrm{AC} \\
\mathrm{AP}\end{array}$ & $\begin{array}{l}6.0 \\
4.5\end{array}$ & $\begin{array}{l}4.5 \\
3.8\end{array}$ & $\begin{array}{l}0 \\
0\end{array}$ \\
\hline MD Anderson & {$[4]$} & $\mathrm{FAC} / \mathrm{P}$ & no data & 1.7 & 2.3 \\
\hline
\end{tabular}

$\mathrm{A}=$ Doxorubicin $; \mathrm{P}=$ paclitaxel $\mathrm{C}=$ cyclophosphamide $\mathrm{M}=$ methotrexate $; \mathrm{F}=5$-fluorouracil $; \mathrm{D}=$ docetaxel; $\mathrm{N}=$ vinorelbine; $\mathrm{X}=$ capecitabine. vs. $10 \%)$. There were no inter-group differences in objective response rates (assessed clinically by mammography or ultrasound). Approximately two-thirds of women in both treatment arms underwent breast-conserving surgery. In the larger trial (91 evaluable patients), 4 cycles of docetaxel $100 \mathrm{mg} / \mathrm{m}^{2}$ achieved a pCR rate of $13 \%$, whereas 4 cycles of intravenous doxorubicin $60 \mathrm{mg} / \mathrm{m}^{2}$ plus cyclophosphamide $600 \mathrm{mg} / \mathrm{m}^{2}$ achieved a rate of $5 \%$. The breast conservation rates with either treatment were statistically similar (48 vs. $34 \%$ ), as were the clinical response rates (62 vs. $59 \%$ ).

The MD Anderson Cancer Center Group [4] compared monotherapy with paclitaxel $250 \mathrm{mg} / \mathrm{m}^{2}$ as 24-hour infusion with 5-fluorouracil/doxorubicin/cyclophosphamide (FAC) at 3-weekly intervals for 4 cycles. 174 patients were randomized and obtained statistically similar clinical and pathological responses with both treatments (table 2).

\section{Taxanes Given Simultaneously with Anthracyclines}

Two trials substituted cyclophosphamide by either doxetaxel or paclitaxel as combination partner for doxorubicin $[5,6]$. Whereas the Anglo-Celtic Cooperative Oncology Group [6] did not observe a difference in response of 363 patients to either doxorubicin/cyclophosphamide or doxorubicin/docetaxel with respect to clinical, pathological, surgical and long-term outcome, the French group of Dieras et al. [5] found a significant increase in pCR from 10 to $16 \%$ if paclitaxel was used instead of cyclophosphamide. In this 200-patient trial, breastconserving surgery was performed in $58 \%$ of patients in the doxorubicin/paclitaxel arm and $45 \%$ of patients in the doxorubicin/cyclophosphamide arm.248 patients with operable breast cancer were treated in the German Gepardo trial [7] with a dose-dense combination of docetaxel $\left(75 \mathrm{mg} / \mathrm{m}^{2}\right)$ and doxoru- bicin $\left(50 \mathrm{mg} / \mathrm{m}^{2}\right)$ with or without simultaneous tamoxifen. In this randomized phase II design, a similar pCR rate (no invasive and non-invasive residuals) of approximately $10 \%$ was found.

The European Cooperative Trial in Operable Breast Cancer (ECTO) [8] randomly tested whether efficacy of adjuvant doxorubicin followed by intravenous cyclophosphamide, methotrexate and 5-fluorouracil (CMF; doxorubicin $\rightarrow \mathrm{CMF}$, arm A) could be improved by adding paclitaxel (doxorubicin/paclitaxel $\rightarrow \mathrm{CMF}$ ) as adjuvant (arm B) or primary systemic therapy (PST; arm C). The clinical complete and partial remission rate in the 1,355 participating women was $78 \%$, with an in-breast pCR rate (including non-invasive residuals) of $23 \%$ and an in-breast plus lymph node pCR rate of $20 \%$. In the multivariate analysis, only estrogen receptor (ER) status was significantly associated with pCR (hazard ratio (HR) for ER-negative: 5.77; 95\% confidence interval: 3.49-9.52; $\mathrm{p}<0.0001)$. Neoadjuvant treatment induced a significant axillary down-staging $(\mathrm{p}<0.001)$, and breast sparing surgery was feasible in 65 vs. $34 \%(\mathrm{p}<0.001)$. After a median followup of 43 months [9], freedom from progression was significantly better for women receiving adjuvant doxorubicin/paclitaxel $\rightarrow$ CMF (arms B and C) than doxorubicin $\rightarrow$ CMF (arm A) (HR 0.65, range $0.48-0.90, p=0.01)$. In a multivariate analysis, treatment inclusive of paclitaxel stood out as significantly associated with progression-free survival (HR 0.66, $\mathrm{p}=0.012$ ), together with clinical diameter $<4 \mathrm{~cm}$, positive progesterone receptor status and negative nodal status. Progression-free survival was not statistically different between patients receiving doxorubicin/paclitaxel $\rightarrow \mathrm{CMF}$ as adjuvant (arm B) or as neoadjuvant (arm C) treatment (HR 0.83, range $0.59-1.16, \mathrm{p}=0.27$ ). Total survival from randomization was similar between all arms in the present analysis. 43 months after surgery, women achieving pCR had a relapse-free sur- 
vival of $89 \%$, compared to $74 \%$ in women who did not reach $\mathrm{pCR}(\mathrm{p}=0.005)$. The incidence of local recurrence was low for women undergoing primary surgery $(4 \%)$ or PST $(4.1 \%)$.

In a phase II pilot study to the Gepartrio trial [10], the German Breast Group (GBG) registered 286 patients to receive 2 neoadjuvant cycles of docetaxel $\left(75 \mathrm{mg} / \mathrm{m}^{2}\right)$, doxorubicin $\left(50 \mathrm{mg} / \mathrm{m}^{2}\right)$, and cyclophosphamide $\left(500 \mathrm{mg} / \mathrm{m}^{2}\right)$ once every 3 weeks (TAC). Response was evaluated by clinical and sonographic examination of the primary tumor. $73 \%$ of these patients showing reduction of the largest diameter by more than $50 \%$ continued TAC treatment for a further 4 cycles. They remained clinical responders in $97 \%$ until surgery, with $51 \%$ showing complete disappearance of all clinical tumor signs. $23 \%$ of these patients achieve pCR. Patients without tumor remission after 2 cycles of TAC were randomized to either continuation of TAC or a non-crossresistant combination schedule of vinorelbine $\left(25 \mathrm{mg} / \mathrm{m}^{2}\right.$, days $1+8$, and capecitabine $\left(2,000 \mathrm{mg} / \mathrm{m}^{2}\right.$, days $\left.1-14\right)(\mathrm{NX})$ for 43 -week cycles. Late clinical response was observed in $62-75 \%$ of the patients with a complete clinical response rate of $20-22 \%$. Pathologic complete disappearance of all malignant cells was found in only $5.5 \%$. The toxicity profile of NX appeared more favorable compared to TAC. Prediction of pCR by response evaluation after a short course of treatment was found to be feasible in this prospective evaluation. Ultrasound appeared more sensitive in identifying patients with a high or low chance of pCR. The pCR rate in operable patients irrespective of their response to the first 2 cycles was $23 \%$ (table 1 ).

In the Gepartrio study of the GBG [11], an individualized treatment approach according to the result of an early efficacy evaluation was chosen. 2,106 patients started neoadjuvant treatment with 2 cycles of TAC. Response of the primary tumor was thereafter evaluated by ultrasound. In 79 patients, further systemic treatment was discontinued due to toxicity, tumor progression, patient request or other reasons. 1,400 patients showed tumor shrinkage by $50 \%$ or more and were randomized to either 4 or 6 further cycles of TAC (data pending). The remaining 627 patients with no sufficient tumor response were randomized to either continuation of TAC for a further 4 cycles or a switch to a non-crossresistant combination of NX. Equal efficacy was found for both treatments with regard to clinical, sonographic or histopathologic response. Despite the low pCR rate of approximately $6 \%$, clinical benefit of further continuing cytotoxic treatment was demonstrated by a breast conservation rate of $60 \%$

\section{Taxanes Given in Sequence to Anthracyclines}

Docetaxel administered sequentially to epirubicin has demonstrated clinical efficacy in several non-comparative studies in women with early or locally advanced breast cancer $(\mathrm{n}=$ $30-61)$ [12-16]. In these studies, the pCR rate was $11-22 \%$, and $12-31 \%$ of women were eligible for breast-conserving surgery. An overall clinical response was seen in $65-91 \%$ of women.

A randomized phase II study [17] in which 45 women with stage II or III breast cancer received 3 or 6 cycles of docetaxel sequential to epirubicin found that the pCR rate was increased 3 -fold with the 6-cycle regimen $(\mathrm{p}<0.05)$. However, similar proportions of patients in either treatment group were eligible for breast-conserving surgery.

In a study with 79 evaluable patients [18], docetaxel administered sequentially after epirubicin/cyclophosphamide/5-fluorouracil achieved an overall clinical response rate of $71 \%$, with $78 \%$ of women achieving breast-conserving surgery. In another study evaluating docetaxel administered sequentially after epirubicin/cyclophosphamide [19], the pCR rate was $24 \%(n=37)$.

In the Aberdeen trial [20], 162 women with large or locally advanced breast cancer were given 4 cycles of cyclophosphamide $1,000 \mathrm{mg} / \mathrm{m}^{2}$ plus doxorubicin $50 \mathrm{mg} / \mathrm{m}^{2}$, vincristine $1.5 \mathrm{mg} / \mathrm{m}^{2}$ and prednisolone $40 \mathrm{mg} /$ day for 5 days (CVAP). Those who responded to treatment were then randomized to either 4 cycles of docetaxel $100 \mathrm{mg} / \mathrm{m}^{2}$ every 21 days $(\mathrm{n}=52)$ or a further 4 cycles of CVAP $(n=52)$ with a 5-day reduced prednisolone dosage of $100 \mathrm{mg} /$ day. Docetaxel sequential to CVAP was more effective than CVAP alone in terms of $\mathrm{pCR}$ rate (34 vs. $16 \% ; \mathrm{p}<0.04$; primary endpoint), overall clinical response ( 94 vs. $66 \% ; p=0.001$ ), and the rate of breast-conserving surgery ( 67 vs. $48 \% ; \mathrm{p}<0.01$ ) in those who completed 8 cycles of chemotherapy (97 evaluable patients). The investigators also reported a significant increase in survival $(\mathrm{p}<0.05)$ in docetaxel recipients at a median follow-up of 3 years. However, this study was statistically not powered to detect such differences.

The MD Anderson group [21] examined the impact of a change in neoadjuvant paclitaxel administration from once every 3 weeks to frequent administration on the pCR rate in the breast and lymph nodes. 258 patients were randomly assigned to receive paclitaxel either weekly (for a total of 12 doses) or once every 3 weeks ( 4 cycles), followed by 4 cycles of FAC in standard doses every 3 weeks. The 2 different doses of paclitaxel used were based on the lymph node status defined by ultrasound and fine needle aspiration (110 patients had histological lymph node involvement and 148 patients had clinical N0 disease). Weekly paclitaxel followed by FAC was administered to 127 patients, and once-every-3-weeks paclitaxel followed by FAC was administered to 131 patients. Clinical response to treatment was similar between both groups $(\mathrm{p}=0.25)$. Patients receiving weekly paclitaxel had a higher pCR rate $(28.2 \%)$ than patients treated once every 3 weeks $(15.7 \% ; \mathrm{p}=0.02)$ and improved breast conservation rates $(\mathrm{p}=$ $0.05)$.

The German AGO group [22] designed a study to compare 2 epirubicin- and paclitaxel-containing regimens given either as dose-dense sequential chemotherapy $(3 \times$ epirubicin $150 \mathrm{mg} / \mathrm{m}^{2}$ followed by $3 \times$ paclitaxel $250 \mathrm{mg} / \mathrm{m}^{2}$ every 2 weeks 
Table 5. Treatment regimens outside of clinical trials recommended by the AGO [37]

\begin{tabular}{lll}
\hline Regimen & Dosage, $\mathrm{mg} / \mathrm{m}^{2}$ & Schedule \\
\hline AC/EC-D & A75, E90, C600, D100 & 4 cycles each, q3w \\
DAC/DEC & D75, A50, E75, C500 & 6 cycles q3w \\
AP-CMF & A60, P200, CMF i.v. & 4 cycles q3w, 4 cycles days $1+8$, q28 \\
\hline
\end{tabular}

$\mathrm{A}=$ Doxorubicin $; \mathrm{C}=$ cyclophophamide $\mathrm{E}$ = epirubicin $; \mathrm{D}=$ docetaxel $\mathrm{P}=$ paclitaxel; $\mathrm{M}=$ methotrexate; $\mathrm{F}=5$-fluorouracil; $\mathrm{q} 3 \mathrm{w}=$ every 3 weeks; $\mathrm{q} 28$ = every 28 days. with granulocyte colony-stimulating factor, G-CSF) or in a standard dose $\left(4 \times\right.$ epirubicin/paclitaxel $90 / 175 \mathrm{mg} / \mathrm{m}^{2}$ every 3 weeks. Results from 475 of 631 randomized patients have been reported so far. The pCR rate (including non-invasive residuals) was $18 \%$ after the dose-dense and $10 \%$ after the conventional treatment $(p=0.03)$. Superior outcome was also demonstrated by a higher breast conservation rate (66 vs. $55 \%)$.

The Geparduo trial [23] compared the efficacy of 4 cycles of doxorubicin $50 \mathrm{mg} / \mathrm{m}^{2}$ plus docetaxel $75 \mathrm{mg} / \mathrm{m}^{2}$ administered every 2 weeks $(\mathrm{n}=451)$ with 4 cycles of docetaxel $100 \mathrm{mg} / \mathrm{m}^{2}$ every 3 weeks sequential to 4 cycles of doxorubicin $60 \mathrm{mg} / \mathrm{m}^{2}$ plus cyclophosphamide $600 \mathrm{mg} / \mathrm{m}^{2}$ every 3 weeks $(\mathrm{n}=453)$ in women with operable breast cancer. Results from 885 evaluable patients with operable breast cancer in this trial of the GBG show a significantly higher pCR rate (breast and axillary nodes) with docetaxel sequential to doxorubicin/cyclophosphamide than dose-dense doxorubicin plus docetaxel (14 vs. $7 \% ; \mathrm{p}<0.001)$ [10]. The overall response rate detected by imaging was also significantly higher ( 79 vs. $69 \%$; $<<0.001 ; n$ $=863$ ), as was the rate of breast-conserving surgery (75 vs. $66 \% ; \mathrm{p}<0.005 ; \mathrm{n}=885)$. Until now, no difference in survival has been found [24].

The NSABP B-27 trial [25] evaluated the effects of adding either preoperative or postoperative docetaxel to preoperative doxorubicin/cyclophosphamide chemotherapy in 2,411 women with operable primary breast cancer. In the 2 neoadjuvant chemotherapy regimens, patients were randomized to receive 4 cycles of doxorubicin $60 \mathrm{mg} / \mathrm{m}^{2}$ plus cyclophosphamide $600 \mathrm{mg} / \mathrm{m}^{2}$ every 3 weeks followed by either surgery or 4 cycles of docetaxel $100 \mathrm{mg} / \mathrm{m}^{2}$ every 3 weeks and then surgery. All patients received tamoxifen $20 \mathrm{mg} /$ day for 5 years beginning on the first day of therapy. Results showed that neoadjuvant chemotherapy with docetaxel sequential to doxorubicin/ cyclophosphamide was superior to doxorubicin/cyclophosphamide. The pCR and complete or partial clinical response rates (primary endpoints) were significantly higher in patients who received docetaxel-containing chemotherapy than in those receiving standard anthracycline-based chemotherapy, as was the overall clinical response rate (complete plus partial responses; 91 vs. $86 \%$; $p<0.001$ ). In addition, significantly fewer patients receiving the docetaxel-containing regimen had positive axillary lymph nodes on pathologic examination (51 vs. $58 \% ; \mathrm{p}<0.001)$. Significant inter-group differences in 5-year disease-free and overall survival rates were not evident, although the proportion of patients achieving relapse-free survival was higher with the docetaxel-containing regimen (HR $0.81 ; \mathrm{p}=0.03)[26]$.

\section{Taxanes Given in Combination or in Sequence with Other Cytotoxic Agents or Trastuzumab}

A high variety of small phase I and II trials exploring new taxane-based regimens are available in the literature. Combination partners are capecitabine, vinorelbine, gemcitabine, platinum analogues, liposomal doxorubicin and others. As the number of patients in these trials is generally low, the impact on future routine practice cannot yet be precisely assessed. Of high interest are trials exploring the potential (synergistic) efficacy of trastuzumab and taxane-based treatments.

Preliminary data from small non-comparative studies $(<50$ patients) indicate that trastuzumab plus taxanes may be an effective treatment option for patients with human epidermal growth factor receptor 2 (HER2/neu)-overexpressing, locally advanced breast cancer [27].

In one small randomized phase II study by the MD Anderson group [28], the neoadjuvant addition of trastuzumab to $4 \mathrm{cy}$ cles of paclitaxel followed by 4 cycles of 5-fluorouracil, epirubicin, and cyclophosphamide was investigated in 42 patients with HER2-positive disease. The initially planned sample size was 164 patients. However, the protocol was stopped by the independent data monitoring committee due to the results of an interim analysis. The decision was based on the calculation that, if the study continued with 164 patients, there was a $95 \%$ probability that trastuzumab plus chemotherapy would be superior. pCR rates were 26 and $65.2 \%$ for chemotherapy $(\mathrm{n}=16)$ and trastuzumab plus chemotherapy $(\mathrm{n}=18)$, respectively $(\mathrm{p}=0.016)$. A more than $10 \%$ decrease in the cardiac ejection fraction was observed in 5 and 7 patients in the chemotherapy and trastuzumab plus chemotherapy arms, respectively.

The AGO breast study group [29] treated within a large nonrandomized phase II trial 230 patients with operable and nonoperable breast cancer with 4 cycles of epirubicin $\left(90 \mathrm{mg} / \mathrm{m}^{2}\right)$ and cyclophosphamide $\left(600 \mathrm{mg} / \mathrm{m}^{2}\right)$ followed by 4 cycles of paclitaxel $175 \mathrm{mg} / \mathrm{m}^{2}$ every 3 weeks. Concomitantly to paclitaxel, trastuzumab was given until surgery and restarted after 


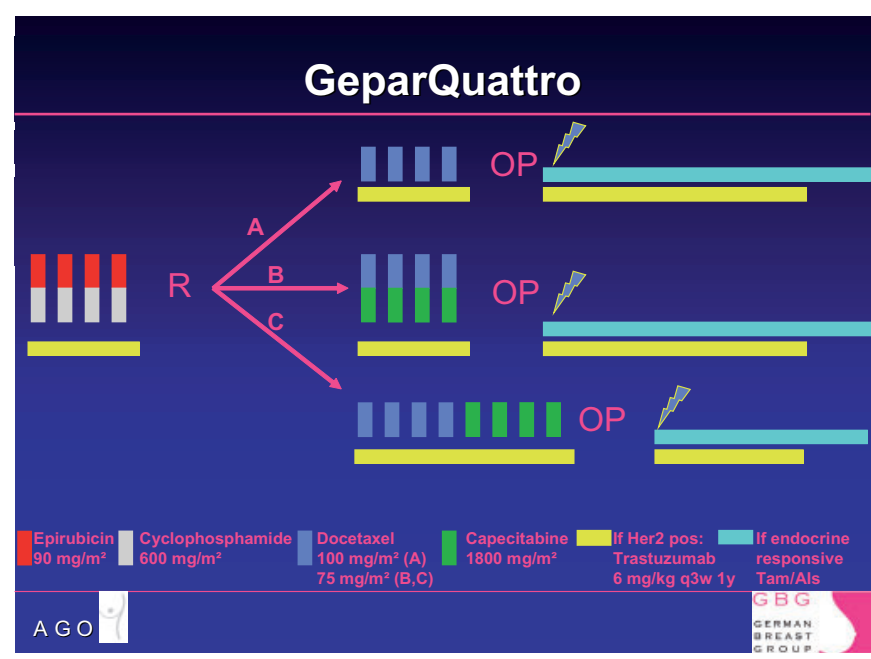

Fig. 1. Design of the GeparQuattro study of GBG and AGO.

surgery for a further 9 months. Histopathologic response was reported for 174 patients, and a pCR rate of $25.3 \%$ (plus additional $16.1 \%$ with in-situ residuals only) was found.

\section{Compliance and Tolerability}

In general, toxicity of neoadjuvant application of systemic treatment does not appear to be more pronounced than postoperative, adjuvant application [25, 34-36]. Few patients withdrew from trials as a result of treatment-related adverse events, e.g. $11 \%$ of neoadjuvant or adjuvant docetaxel recipients in the NSABP B-27 [25]; 7\% (5 CVAP and 7 docetaxel sequential to CVAP recipients) in the Aberdeen trial [20]; 6\% of doxorubicin/docetaxel and $13 \%$ of docetaxel sequential to doxorubicin/cyclophosphamide recipients in the Geparduo trial $\left.{ }^{[23}\right]$ (table 4).

Only very few patients $(0.8-4.5 \%)$ will not have surgery after application of neoadjuvant systemic therapy. This might be due to progressive disease of locally advanced, inoperable cancers, severe (fatal) toxicity of chemotherapy, or withdrawal of consent (table 4).

The switch to a another regimen in patients that do not respond early can obtain similar efficacy but may produce less toxicity, e.g. 4 cycles of NX without the need for G-CSF after 2 cycles of TAC appeared to have less hematological toxicity and mucositis of the mouth, conjunctives, esophagus and bowels, but produced more hand-foot syndrome and sensory neuropathy [11].

\section{What Regimen Should be Used Outside of Clinical Trials?}

Today, sequential administration of anthracyclines and taxanes for more than 4 cycles in total can be considered as the best option where tumor operability is to be improved. The

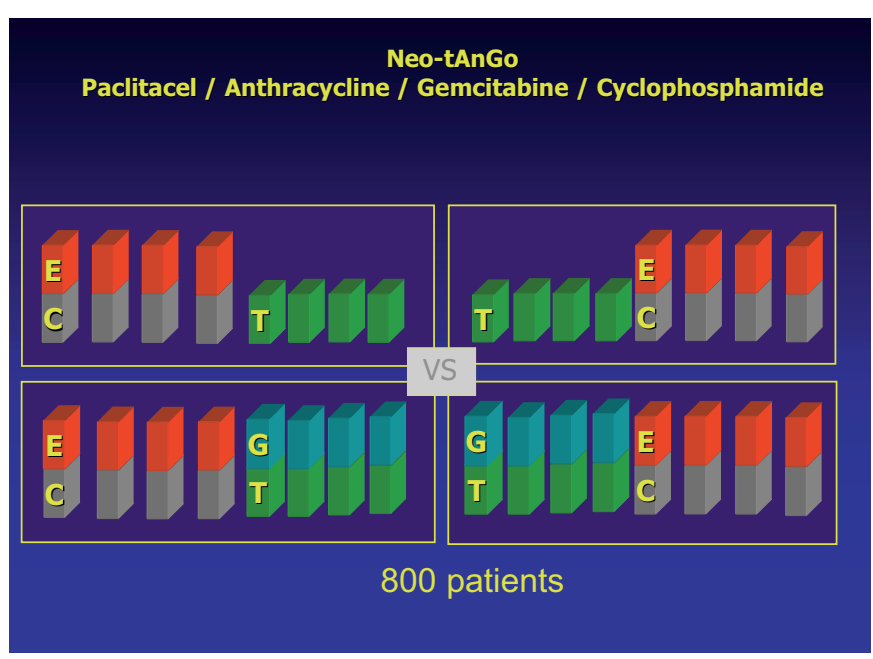

Fig. 2. Design of the current Neo-tAnGo study (UK).

doxorubicin/cyclophosphamide followed by docetaxel regimen has been assessed in 2 large randomized trials and showed superiority to 4 cycles of doxorubicin/cyclophosphamide or 4 cycles of a dose-dense combination of doxorubicin and docetaxel. In both trials, tamoxifen was given simultaneously to chemotherapy. However, this is not recommended today, as it may deteriorate the efficacy of the cytotoxic agents. It remains an open question whether the supplementation of the taxane or the duration of treatment is more important. Other sequential treatments that have been explored in large phase III trials are doxorubicin/docetaxel followed by $\mathrm{CMF}^{[8]}$ and a dose-dense sequence of epirubicin and paclitaxel [22] (table 5). Recently, high pCR rates have been reported for weekly administration of paclitaxel or the addition of trastuzumab to cytotoxic treatment. However, these results have to be confirmed by larger, multicenter trials.

\section{Outlook}

Taxane-based neoadjuvant chemotherapies need to be further optimized. Various strategies are currently under investigation. In larger scale trials, the addition of other cytotoxic agents including capecitabine, gemcitabine, liposomal doxorubicin and vinorelbine are currently under way. An important question is whether these new components should be introduced into the regimen by simultaneous or sequential administration with taxanes. The current GeparQuattro study (fig. 1) is addressing this issue. It remains controversial whether, if a sequence is chosen, taxanes should be given before or after the anthracycline-based part, which is currently investigated by the Neo-tAnGo study in the UK (fig. 2). The next generation of phase II/III trials will include a wide range of new target-specific agents, such as dual HER1/HER2 receptor antagonists, antiangiogenic drugs and mTor antagonists. Trials are planned where these new compounds are given in combina- 
tion with taxane monotherapy or taxane/anthracycline-based regimens.

A broad field of further investigations is aimed at selecting the right patients for a specific treatment. The more practical approach aims at using early response evaluation after the first few treatment cycles to select patients with a higher or a lower chance of $\mathrm{pCR}$ and to then individualize therapy according to the expected response (e.g. design of the Gepar- trio study). The more molecular biological approach tries to identify groups of patients with specific tumor genotypes by gene arrays on the core biopsy tissue that will have a high or a low chance to respond to a specific treatment [30]. However, methodological instability of the detection method as well as logistic problems in centrally assessed samples from patients participating in multicenter trials have yet to be resolved.

\section{References}

1 Kaufmann M, von Minckwitz G, Smith R, et al.: International expert panel on the use of primary (preoperative) systemic treatment of operable breast cancer: review and recommendations. J Clin Oncol 2003;21:2600-28.

2 Bougnoux P, Combe M, Goudier MJ, et al.: Phase II randomized trial of docetaxel monotherapy vs epirubicin plus docetaxel as neoadjuvant treatment of operable breast cancer. J Clin Oncol 2004;22 (suppl):abstr 599.

3 Makris A, Hisenbeck SG, Yee D, et al.: A prospective randomized multicenter gene expression study of docetaxel vs doxorubicin/cyclophosphamide preoperative trial in primary breast cancers. J Clin Oncol 2005;23(suppl):abstr 544.

4 Buzdar AU, Singletary SE, Theriault RL, et al.: Prospective evaluation of paclitaxel versus combination chemotherapy with fluorouracil, doxorubicin, and cyclophosphamide as neoadjuvant therapy in patients with operable breast cancer. J Clin Oncol 1999;17:3412-7.

$\checkmark 5$ Dieras V, Fumoleau P, Romieu G, Tubiana-Hulin M, Namer M, Mauriac L, Guastalla JP, Pujade-Lauraine E, Kerbrat P, Maillart P, Penault-Llorca F, Buyse M, Pouillart P: Randomized parallel study of doxorubicin plus paclitaxel and doxorubicin plus cyclophosphamide as neoadjuvant treatment of patients with breast cancer. J Clin Oncol 2004;22: 4958-65.

6 Evans TRJ, Yellowlees A, Foster E, et al.: Phase III randomized trial of doxorubicin and docetaxel versus doxorubicin and cyclophosphamide as primary medical therapy in women with breast cancer: an Anglo-Celtic Cooperative Oncology Group Study. J Clin Oncol 2005;23:2988-2995.

7 Von Minckwitz G, Costa SD, Raab G, et al.: Dosedense doxorubicin, docetaxel, and granulocyte colony-stimulating factor support with or without tamoxifen as preoperative therapy in patients with operable carcinoma of the breast: a randomized, controlled, open phase IIb study. J Clin Oncol 2001; 19:3506-15.

8 Gianni L, Baselga J, Eiermann W, Guillem Porta V, Semiglazov V, Lluch A, Zambetti M, Sabadell D, Raab G, Llombart Cussac A, Bozhok A, MartinezAgullo A, Greco M, Byakhov M, Lopez Lopez JJ, Mansutti M, Valagussa P, Bonadonna G: European Cooperative Trial in Operable Breast Cancer Study Group. Feasibility and tolerability of sequential doxorubicin/paclitaxel followed by cyclophosphamide, methotrexate, and fluorouracil and its effects on tumor response as preoperative therapy. Clin Cancer Res 2005;11:8715-21.
9 Gianni L, Baselga J, Eiermann W, et al.: European Cooperative Trial in Operable Breast Cancer (ECTO): Improved freedom from progression (FFP) from adding paclitaxel (T) to doxorubicin (A) followed by cyclophosphamide methotrexate and fluorouracil (CMF). J Clin Oncol 2005;23 (suppl):abstr 513.

10 Von Minckwitz G, Blohmer JU, Raab G, Lohr A, Gerber B, Heinrich G, Eidtmann H, Kaufmann M, Hilfrich J, Jackisch C, Zuna I, Costa SD: In vivo chemosensitivity-adapted preoperative chemotherapy in patients with early-stage breast cancer: the GEPARTRIO pilot study. Ann Oncol 2005;16: 56-63.

11 Von Minckwitz G, Blohmer JU, Loehr A, Raab G, Eidtmann H, Hilfrich J, Gerber B, Huober J, Costa SD, Jackisch C, Loibl S, Schickling O, Zuna I, Kaufmann M: Comparison of docetaxel/doxorubicin/ cyclophosphamide (TAC) versus vinorelbine/ capecitabine $(\mathrm{NX})$ in patients non-responding to 2 cycles of neoadjuvant TAC chemotherapy first results of the phase III GEPARTRIO Study by the German Breast Group. Breast Cancer Res Treat 2005;94(suppl):abstr 38.

12 Chen SC, Chang HK, Lin YC, et al.: Response rate with weekly epirubicin and docetaxel as neoadjuvant chemotherapy for locally-advanced breast cancer J Clin Oncol 2005;23(suppl):99s, abstr 885.

13 Lorenzo A, Madronal C, Sanz JJ, et al.: Phase II study of dose-dense docetaxel and epirubicin as neoadjuvant treatment for locally advanced breast cancer. An ONCOPAZ Cooperative Group study. J Clin Oncol 2005;23(suppl):72s, abstr 779.

14 Nishimura R, Rai Y, Mitsuyama S, et al.: Phase II study of epirubicin and docetaxel as neoadjuvant chemotherapy in patients with large breast cancer (stage II-III, tumor size greater than $3.0 \mathrm{~cm}$ ). Kyushu ET Study Group in Japan. Breast 2005;14 (suppl 1):S41-2, abstr P93.

15 Espinosa E, Morales S, Borrega P, et al.: Docetaxel and high-dose epirubicin as neoadjuvant chemotherapy in locally advanced breast cancer. Cancer Chemother Pharmacol 2004;54:546-52.

16 de Matteis A, Nuzzo F, D'Aiuto G, et al.: Docetaxel plus epidoxorubicin as neoadjuvant treatment in patients with large operable or locally advanced carcimona of the breast: a single-centre, phase II study. Cancer 2002;94:895-901.

17 Reitsamer R, Peintinger F, Prokop E, et al.: Pathological complete response rates comparing 3 versus 6 cycles of epidoxorubicin and docetaxel in the neoadjuvant setting of patients with stage II and III breast cancer. Anticancer Drugs 2005;16:867-70.
18 Iwata H, Nakamura S, Toi M, et al.: Interim analysis of a phase II trial of cyclophosphamide, epirubicin and 5-fluorouracil (CEF) followed by docetaxel as preoperative chemotherapy for early stage breast carcinoma. Breast Cancer 2005;12: 99-103.

19 Cramer EM, Moers C, Zarghooni V, et al.: Neoadjuvant, biweekly, dose-dense chemotherapy with epirubicin and cyclophosphamide followed by docetaxel in primary breast cancer. J Clin Oncol 2005;23(suppl 16):82s, abstr 820.

20 Smith IC, Heys SD, Hutcheon AW, et al.: Neoadjuvant chemotherapy in breast cancer significantly enhanced response to docetaxel. J Clin Oncol 2002; 20:1456-66.

21 Green MC, Buzdar AU, Smith T, et al.: Weekly paclitaxel improves complete remission in operable breast cancer when compared with paclitaxel once every 3 weeks. J Clin Oncol 2005;23:5982-92.

22 Untch M, Konecny G, Ditsch N, et al.: Dose-dense sequential epirubicin-paclitaxel as preoperative treatment of breast cancer: results of a randomised AGO study. J Clin Oncol 2002;21(suppl):34a, abstr 1863.

23 Von Minckwitz G, Raab G, Caputo A, Schütte M, Hilfrich J, Blohmer JU, Gerber G, Costa SD, Merkle E, Eidtmann H, Lampe D, Jackisch C, du Bois A, Kaufmann M: Preoperative sequential versus dose-dense combination therapy with doxorubicin and docetaxel in operable breast cancer. J Clin Oncol 2005;23:2676-85.

24 Raab G, Kaufmann M, Schuette M, Hilfrich J, Blohmer JU, Gerber B, Costa SD, Eidtmann H, Eiermann W, Lampe D, Jackisch C, du Bois A, von Minckwitz G: Preoperative doxorubicin / cyclophosphamide followed by docetaxel (AC-Doc) versus dose-dense doxorubicin and docetaxel (Adoc) as preoperative treatment in operable breast cancer: first analysis of the event-free survival of the GeparDuo Study. Breast Cancer Res Treat 2005; 94(suppl 1):abstr 5047.

25 Bear HD, Anderson S, Brown A, et al.: The effect on tumor response of adding sequential preoperative docetaxel to preoperative doxorubicin and cyclophosphamide: preliminary results from National Surgical Adjuvant Breast and Bowel Project Protocol B-27. J Clin Oncol 2003;21:4165-74.

26 Bear HD, Anderson S, Smith RE, et al.: A randomized trial comparing preoperative (preop) doxorubicin/cyclophosphamide (AC) to preop $\mathrm{AC}$ followed by preop docetaxel (T) and to preop AC followed by postoperative (postop) $\mathrm{T}$ in patients (pts) with operable carcinoma of the breast: results of NSABP B-27. Breast Cancer Res Treat 2004;88: abstr 16 . 
-27 Kaufmann M, Hortobagyi GN, Goldhirsch A, Scholl S, Makris A, Valagussa P, Blohmer JU, Eiermann W, Jackesz R, Jonat W, Lebeau A, Loibl S, Miller W, Semiglazov V, Smith R, Seeber S, Souchon R, Stearns V, Untch M, von Minckwitz G: Recommendations from an international expert panel on the use of neoadjuvant (primary) systemic treatment of operable breast cancer: an update. J Clin Oncol 2006;24(12):1940-9.

28 Buzdar AU, Ibrahim NK, Francis D, et al.: Significantly higher pathologic complete remission rate after neoadjuvant therapy with trastuzumab, paclitaxel, and epirubicin chemotherapy: results of a randomized trial in human epidermal growth factor receptor 2-positive operable breast cancer. J Clin Oncol 2005;23:3676-85.

29 Untch M, Stoeckl D, Konecny G, et al.: A multicenter phase II study of preoperative epirubicin, cyclophosphamide (EC) followed by paclitaxel (P) plus trastuzumab $(\mathrm{T})$ in Her2 positive primary breast cancer. Breast Cancer Res Treat 2005;94 (suppl 1):abstr 1064

30 Rody A, Karn T, Munnes M, von Minckwitz G, Loibl S, Solbach C, Holtrich U, Kaufmann M: Gene expression profiles of breast cancer obtained from core cut biopsies before neoadjuvant docetaxel, doxorubicin and cyclophoshamide chemotherapy correlate with routine prognostic markers and could be used to identify predictive signatures. J Clin Oncol 2005;23(suppl):abstr 646.

31 Evans TRJ, Yellowlees A, Foster E, et al.: Phase III randomized trial of doxorubicin and docetaxel versus doxorubicin and cyclophosphamide as primary medical therapy in women with breast cancer: an Anglo-Celtic Cooperative Oncology Group Study. J Clin Oncol 2005;23:2988-95.

32 Moliterni A, Bolognesi A, Mansutti M, et al.: Feasibility and locoregional activity of primary chemotherapy (PC) with doxorubicin/paclitaxel (AT) versus epirubicin/vinorelbine $(\mathrm{EV})$ in operable breast cancer. A study by the Michelangelo Foundation. Breast Cancer Res Treat 2004;88:abstr 106.

33 Steger GG, Kubista E, Hausmaninger H, et al.: 6 vs. 3 cycles of epirubicine/docetaxel + G-CSF in operable breast cancer. J Clin Oncol 2004;22:abstr 15.

34 Fisher B, Brown A, Mamounas E, et al.: Effect of preoperative chemotherapy on local-regional disease in women with operable breast cancer: findings from National Surgical Adjuvant Breast and Bowel Project B-18. J Clin Oncol 1997;15:2483-93.

35 Therasse P, Mauriac L, Welnicka-Jaskiewicz M, et al.: Final results of a randomized phase III trial comparing cyclophosphamide, epirubicin, and fluorouracil with a dose-intensified epirubicin and cyclophosphamide + filgrastim as neoadjuvant treatment in locally advanced breast cancer: an EORTC-NCIC-SAKK multicenter study. J Clin Oncol 2003;21:843-50.

-36 Scholl SM, Fourquet A, Asselain B, Pierga JY, Vilcoq JR, Durand JC, Dorval T, Palangie T, Jouve M, Beuzeboc P, et al.: Neoadjuvant versus adjuvant chemotherapy in premenopausal patients with tumours considered too large for breast conserving surgery: preliminary results of a randomised trial: S6. Eur J Cancer 1994;30A:645-52.

37 www.ago-online.org. 